\title{
Strengthening of Reinforced Concrete Slab-Column Connection Subjected to Punching Shear with FRP Systems
}

\author{
G. I. Khaleel, I. G. Shaaban, K. M. Elsayedand, and M. H. Makhlouf
}

\begin{abstract}
This study aims to determine the efficiency of using Fiber Reinforced Polymers (FRP) systems to strengthen the slab-column connections subjected to punching shear. The used strengthening systems consisted of external FRP stirrups made from glass and carbon fibers. The stirrups were installed around the column. Also, external steel links were used as a conventional strengthening method for comparison. Over the last few years, the use of FRP for strengthening of concrete structures has been investigated by many researchers, whichconcerning with the strengthening of reinforced concrete slabs, beams and columns. The use of FRP in strengthening concrete slabs in flexure is done by bonding it to the tension face of the slabs. The use of FRP for strengthening the flat slabs against punching shear can be considered as a new application. This research shows the results obtained from an experimental investigation of 4 half-scale two-way slab-column interior connections, which were constructed and tested under punching shear caused by centric vertical load. The research included one unstrengthened specimen, which considered as control specimen, one specimen strengthened with steel links, one specimen strengthened with external stirrups made from Glass Fiber Reinforced Polymer (GFRP), and one specimen strengthened with external stirrups made from Carbon Fiber Reinforced Polymer (CFRP). So, the type of strengthening material is the basic parameter in this study. The experimental results showed a noticeable increase in punching shear resistance and flexural stiffness for the strengthened specimens compared to control specimen. Also, the strengthened tested slabs showed a relative ductility enhancement. Finally, equations for punching shear strength prediction of slab-column connections strengthened using different materials (Steel, GFRP \& CFRP) were applied and compared with the experimental results.
\end{abstract}

Index Terms-Fiber reinforced polymer, punching shear, reinforced concrete slab-column connection, Strengthening and repair.

\section{INTRODUCTION}

Punching shear failures are usually sudden and catastrophic. Such failure is undesirable as they do not allow an overall yield mechanism to develop before punching [1]. Many failures of flat slab structures were reported during construction [2], and in many cases punching shear failures initiated and led to progressive collapse, specially, when lower floors have failed to support the impact of the above ones. This brittle failure occurs without much warning.

There are mainly two ways to increase the punching shear

Manuscript received March 15, 2013; revised June 29, 2013.

The authors are with the Civil Engineering Department, Faculty of Engineering in Benha, Benha University, Egypt (e-mail: gamal22_2@yahoo.com, igshaaban@mailer.eun.eg, khelsayed@hotmail.com; mohamedmakhlouf83@yahoo.com). strength of concrete slabs: 1 - increasing the slab thickness in the vicinity of the column by providing a drop panel or a column head; 2- Providing shear reinforcement. Sometimes, after the construction of some building, the increase of punching shear resistance for reinforced concrete slab-column connection may be needed. The strengthening of slab-column connection against punching shear resistance by using traditional methods (steel plates, steel stirrups, steel studs, or increasing concrete dimensions) was studied [3-5]. Few studies concerned with using the FRP strengthening systems for flat slabs [6]. The present study aims to evaluate the using of FRP materials to increase the punching shear resistance of concrete slab-column. The values of punching shear strength were predicted taking into account the contribution of the applied strengthening systems. The calculated values were compared with the corresponding experimental results in order to evaluate the used equations.

\section{EXPERIMENTAL PROGRAM}

All specimens were tested under punching shear caused by centric vertical load till failure. The experimental results included the maximum load which presents the punching shear strength of the tested specimens, the load deflection curves, and the crack patterns of each tested specimen.

\section{TESTED SPECIMENS}

The tested specimens were chosen as rectangular slabs of $110 \times 110 \times 10 \mathrm{~cm}$ dimensions with an average effective depth of $8 \mathrm{~cm}$. Stub column having $15 \times 15 \mathrm{~cm}$ cross section. The column with $80 \mathrm{~cm}$ total height was cast monolithically at the center of the slab and extended outside both sides of the slab as shown in Fig. 1.

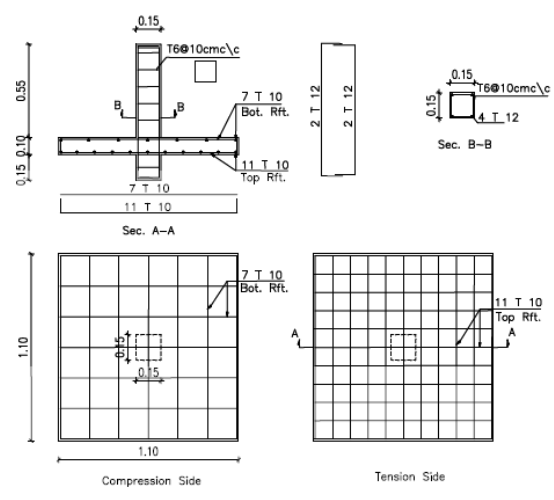

Fig. 1. Details of tested RC specimen 
The tested specimens were designed to be simply supported along the four edges with clear spans of $100 \mathrm{~cm}$ in both directions, and the corners were free to rise. This test arrangement is convenient to simulate the actual boundary conditions in the prototype.

High tensile steel bars of $10 \mathrm{~mm}$ diameters were used as top and bottom reinforcement. The tension reinforcement was $11 \Phi 10 \mathrm{~mm}$ and the compression reinforcement was $7 \Phi 10 \mathrm{~mm}$ in both directions. The concrete columns were reinforced with $4 \Phi 12$ longitudinal high tensile steel bars and with normal mild steel $6 \mathrm{~mm}$ every $10 \mathrm{~cm}$ as stirrups. Full details of the slab-column connection, are shown in Fig. 1. The properties of the four tested specimens are shown in Table I, the strengthened specimens were divided into three specimens in addition to the control specimen.

TABLE I: THE PROPERTIES OF TESTED SPECIMENS
\begin{tabular}{|c|c|c|}
\hline Notation & Specimen state & Strengthening type \\
\hline SPH & Control & none \\
\hline SPS & Strengthened & Steel Links \\
\hline SPG & Strengthened & GFRP stirrups \\
\hline SPC & Strengthened & CFRP stirups \\
\hline
\end{tabular}
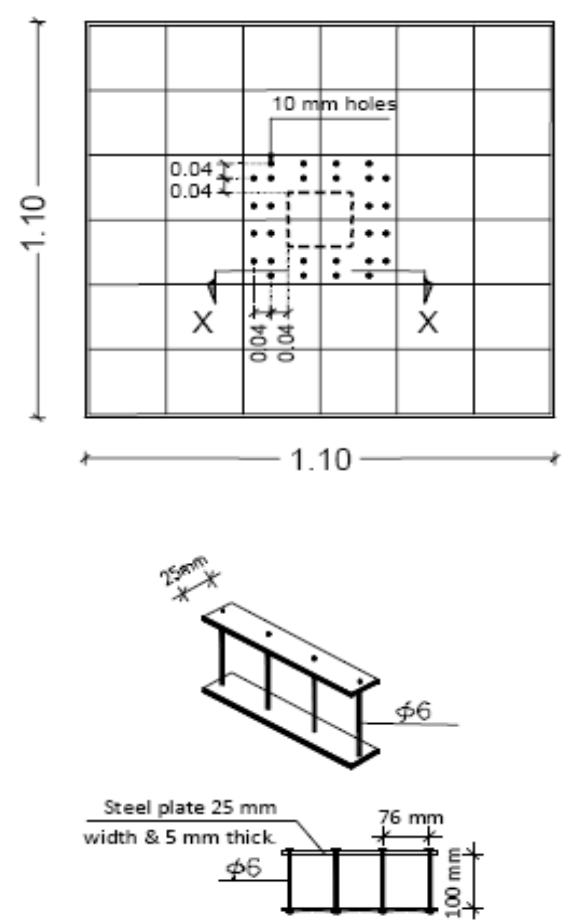

$\underline{\text { Sec. } X-X \text { in case of steel links }}$

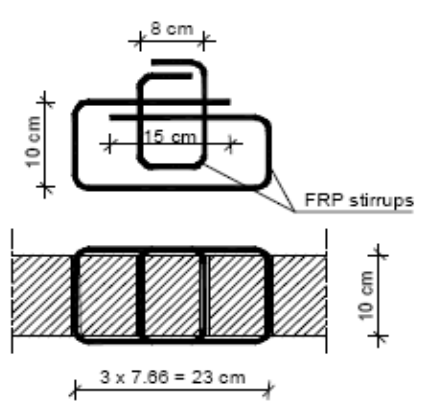

Sec. X-X in case of FRP stirrups

Fig. 2. The shape and dimensions of different strengthening systems

\section{MATERIAls Properties}

The specimens were cast using normal strength concrete of 30 MPacharacteristic strength. The concrete mix was prepared in the concrete Lab of Benha faculty of Engineering using Ordinary Portland cement, clean siliceous sand, crushed lime stone, and potable water. Tests were carried out according to ECP-203-07 and Egyptian standards to define the properties for concrete constituents, concrete mix and reinforcement steel. Table II gives the properties of the GFRP WR and CFRP wraps used in this work, given by the manufacturer.

TABLE II: MECHANICAL PROPERTIES OF GFRP AND CFRP WRAPS [7]

\begin{tabular}{lcc}
\hline \multicolumn{1}{c}{ Property } & $\begin{array}{c}\text { Glass Fiber Woven Roving } \\
\text { Wraps (WR) }\end{array}$ & $\begin{array}{c}\text { CFRP } \\
\text { (Sika Wrap } \\
\text { Hex-230C) }\end{array}$ \\
\hline Fabric thickness, $\mathrm{mm}$ & 0.17 & 0.12 \\
\hline Tensile strength, $\mathrm{MPa}$ & 284 & 4020 \\
\hline Modulus of elasticity, $\mathrm{MPa}$ & 74000 & 225000 \\
\hline Elongation at failure, $\%$ & 2.0 & 1.7 \\
\hline \hline
\end{tabular}

\section{TEST SET-UP}

The slab specimens were mounted in a horizontal position inside the steel frame, and the load was applied to the stub-column in a vertical direction using a hydraulic jack of 50 ton capacity, as shown in Fig. 3.

The development of cracks was observed during loading on both faces of the slab. Dial gauges of $0.01 \mathrm{~mm}$ accuracy and $50 \mathrm{~mm}$ total range were used to measure the deflection at the bottom face of the slab (tension side). The dial gauges were fixed at the center of the slab to record the maximum deflection, and at the supports which considered a datum level to get the net deflection values of the slab. Load was applied on successive increments. Slab deflection, and cracking conditions were recorded after each increment till slab failure.

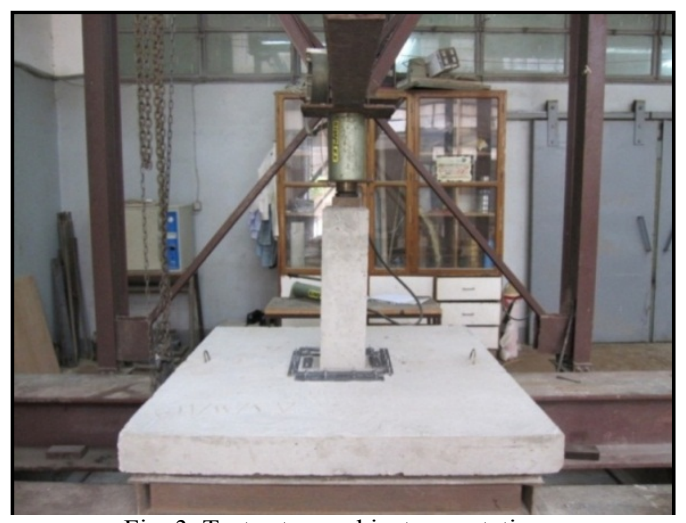

Fig. 3. Test setup and instrumentations

\section{STRENGTHENING Systems}

\section{A. Using Steel Links}

The proposed conventional strengthening system consisted of steel links which were locally fabricated using normal tensile steel bars of $6 \mathrm{~mm}$ diameter fixed at both ends by two steel plates of $5 \mathrm{~mm}$ thickness and $25 \mathrm{~mm}$ width. Steel links 
were installed through the holes which penetrated the total slab thickness. The clearance between steel links and holes was filled by polyester to ensure good bond between concrete and steel links.

\section{B. Using FRP Stirrups}

Specimens were strengthened by using intertwined FRP rods which were manually manufactured from fiber wraps of $6 \mathrm{~mm}$ diameter stirrups which prepared from $4 \mathrm{~cm}$. Vertical holes with $10 \mathrm{~mm}$ diameter were drilled in the slabs. The FRP wraps were saturated with polyester for GFRP and epoxy resin (Sikadur-330) for CFRP, and then the intertwined rods were formed and stitched through holes along the thickness of the slab. 24 hours later, the clearance between GFRP or CFRP stirrups and holes was filled by polyester or Sikadur-330, respectively, to ensure good bond between FRP stirrups and concrete.

\section{EXPERIMENTAL RESULTS AND DISCUSSION}

For each tested specimen, the complete load deflection curve was plotted and the cracks propagation was recorded. The obtained results were analyzed and discussed in order to study the effect of strengthening material type on the mechanical behavior of the slab-column connections under punching shear.

\section{A. Cracking Behavior and Failure Mode}

All the tested specimens were loaded under centric vertical load and failed due to shear punching. The cracks appeared firstly at the tension side of the slab. For each tested specimen, the load value corresponding to cracking initiation (Vcr) is shown in Table III. The strengthening of the specimen caused a significant increase of the first crack load. Using steel links, GFRP and CFRP stirrups led to improve its value by $29 \%, 35 \%$ and $47 \%$, respectively, in comparison with control specimen.

As the applied load increased, the cracks propagated and became wider and new cracks appeared as well. The radial cracks propagated in several directions towards the slab edges forming a van shape. The failure surface intersected with the slab bottom surface forming a circumferential crack of nearly square shape. The distance between the column face and the surrounding failure crack was larger in case of strengthened specimens. Also, a higher number of radial cracks were observed for strengthened specimens in comparison with control specimen, as shown in Fig. 4. The number of radial cracks was 11 for control specimen; however, it increased to $20 \& 23$ when steel links and FRP stirrups were applied, respectively.

\section{B. Load-Deflection Plots}

For all tested specimens, the deflection value, measured at the central point, was recorded at each load increment, and the load-deflection relationship was plotted. Fig. 5 shows a comparison between the different strengthened specimens, also the load-deflection plot of the control specimen was presented in the same figure for comparison. Although the ultimate load of the strengthened specimens was different, the load-deflection relationships of these specimens were moderately similar. All the strengthening materials led to a significant increase of the rigidity and the resistance of the tested specimens against the shear punching. At the same loading level, lower deflection values were recorded for strengthened specimens, either with steel links, GFRP or CFRP stirrups, in comparison with the control specimen, as shown in Fig. 5.

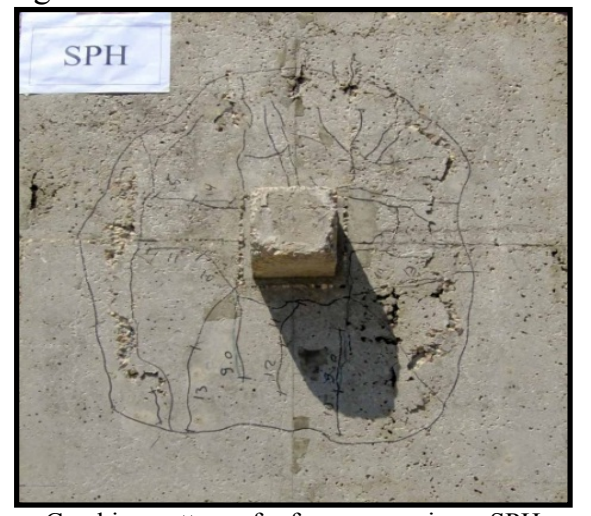

Cracking pattern of reference specimen SPH

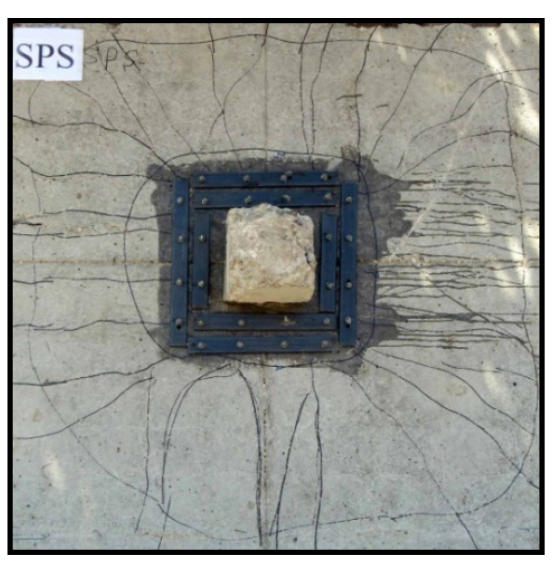

Cracking pattern of specimen SPS

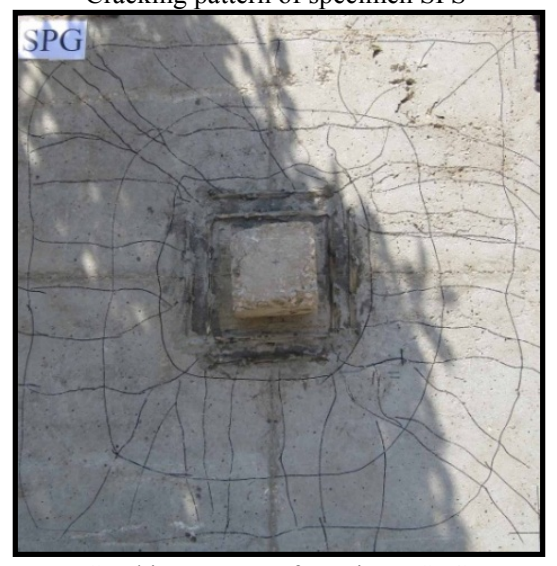

Cracking pattern of specimen SPG

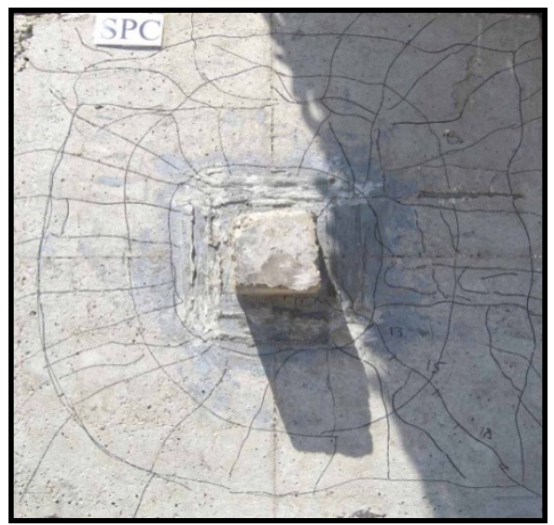

Cracking pattern of specimen SPC

Fig. 4. Cracking patterns 


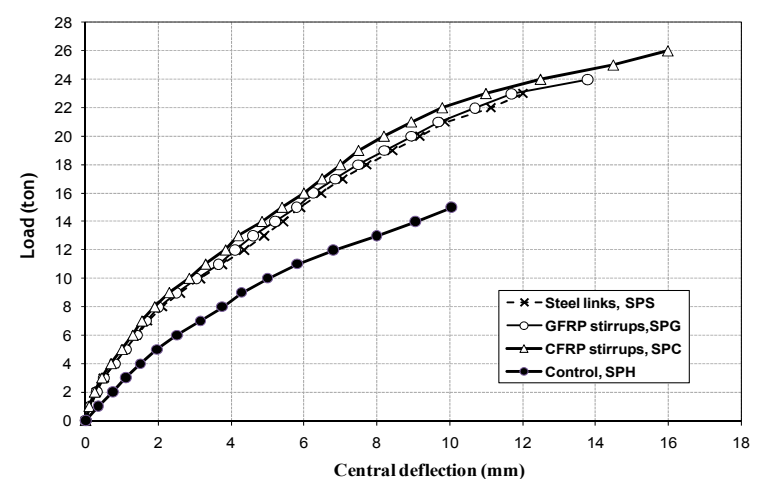

Fig. 5. Comparison between load-deflection plots of the tested specimens

\section{Ultimatepunching Shear Strength}

Table III shows the ultimate load $\left(V_{u}\right)$ recorded experimentally for the tested specimens. The use of steel links gave an increase of ultimate load by $60 \%$ of that recorded for control specimen. The use of GFRP and CFRP stirrups with the same number of rows and the same diameter as the steel links increased of the ultimate load by $60 \%$ and $73 \%$, respectively. Fig. 6 shows a comparison between the tested specimens with respect to cracking and ultimate loads.

TABLE III: EXPERIMENTAL RESULTS
\begin{tabular}{|c|c|c|c|}
\hline Slab Code & $V_{u, \text { exp }}($ ton $)$ & $V_{u, c a l}($ ton $)$ & $V_{u \text {,exp. }} / V_{u, c a l}$ \\
\hline SPH & 15 & 12.15 & 1.23 \\
\hline SPS & 24 & 18.49 & 1.29 \\
\hline SPG & 24 & 21.30 & 1.12 \\
\hline SPC & 26 & 22.60 & 1.15 \\
\hline
\end{tabular}

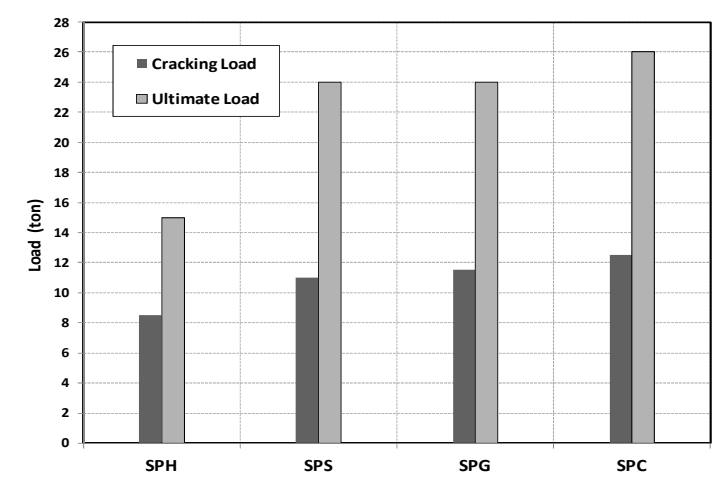

Fig. 6. Effect of strengthening types on cracking and ultimate Load

\section{ANALYTICAL MODELING}

All the tested specimens failed as a result of concrete exhaustion under punching shear stress at the critical section located at a distance $d / 2$ from the outermost row of punching shear reinforcement. For the prediction of the ultimate test loads, the following equation can be used to calculate the values of concrete nominal punching shear strength $\left(V_{c}\right)$ [8];

$$
v_{c}=0.33\left(1-\frac{\alpha-1}{6}\right) \sqrt{f_{c^{\prime}}} \quad M P a
$$

where;

$\alpha$ : ratio of the critical section distance from the column face to the slab effective depth $4 \geq \alpha \geq 1$;

$f_{c}^{\prime}$ : concrete cylinder compressive strength;

For the specimens reinforced with shear reinforcement or strengthened with steel links the nominal punching shear strength may be expressed as:

$$
V_{n}=V_{c}+V_{s}
$$

where;

$V_{c}$ : shear resisted by the concrete;

$V_{s}:$ shear resisted by reinforcement;

$$
V_{s}=\left(A_{c} \cdot f_{y v} \cdot d\right) / S
$$

where;

$A_{v}$ : area of the vertical legs forming the shear reinforcement units in one row;

$f_{y v}$ : yield stress of the used steel for shear reinforcement units;

$S$ : spacing between rows;

The shear force resisted by the concrete at any critical section can be calculated from the following equation;

$$
V_{c}=v_{c} \cdot b \cdot d
$$

where;

$v_{c}$ : given by (1);

$b:$ perimeter of the critical section (at a distance $d / 2$ from the outermost row of punching shear reinforcement);

In specimens strengthened with FRP, the nominal punching shear strength may be expressed as:

$$
V_{n}=V_{c}+V_{f}
$$

where;

$V_{f}$ is the shear resisted by fiber reinforcement;

The shear strength provided by the fiber reinforcement $\left(V_{f}\right)$ can be determined by calculating the force resulting from the effective tensile stress in the fiber $\left(f_{f e}\right)$ which depends on its effective strain $\left(\epsilon_{f e}\right)$.

$$
\begin{aligned}
& V_{f}=\left(A_{f v} \cdot f_{f e} \cdot d_{f}\right) / S_{f} \\
& A_{f v}=n_{s} \cdot n_{v} \cdot t_{f} \cdot w_{f} \\
& f_{f e}=\varepsilon_{f e} \cdot E_{f}
\end{aligned}
$$

where;

$\epsilon_{f e}=0.004$ (for completely wrapping all 4 sides) [9];

$S_{f}$ : spacing between fiber rows;

$t_{f}$ :fiber reinforcement thickness;

$w_{f}$ : width of the fiber strip;

$n_{v}$ : number of side row stirrups;

$n_{s}$ : number of vertical legs in one side of row;

$A_{f v}:$ area of fiber in one row;

$d_{f}$ : depth of fiber stirrups.

The above equations were applied to predict the ultimate punching shear load of the tested specimens. Table IV shows a comparison between the calculated values of the ultimate load $\left(V_{u}\right.$, cal. $)$ and the corresponding experimental values $\left(V_{u, \text { exp. }}\right)$. The equations used to predict the ultimate loads are moderately conservative, where the experimental values are higher than the calculated ones by $12 \%$ to $29 \%$.

TABLE IV: COMPARISON OF BETWEEN THE CALCULATED AND EXPERIMENTAL ULTIMATE LOADS

\begin{tabular}{ccccc}
\hline \hline Slab Code & $V_{c r}$ (ton) & $V_{u}$ (ton) & $V_{\text {wexp. }} / V_{w \text { ref. }}$ & $\begin{array}{c}\text { Max. Deflection } \\
(\mathrm{mm})\end{array}$ \\
\hline SPH & 8.5 & 15 & 1.00 & 9.0 \\
\hline SPS & 11.0 & 24 & 1.60 & 13.4 \\
\hline SPG & 11.5 & 24 & 1.60 & 13.8 \\
\hline SPC & 12.5 & 26 & 1.73 & 16.0 \\
\hline \hline
\end{tabular}




\section{CONCLUSION}

Based on the research work, the following conclusions and recommendation can be summarized:

1) All the specimens failed due to punching shear.

2) All the materials used in this research to strengthen the slab-column connection were effective and improved significantly the shear punching behavior in terms of flexural rigidity, initial cracking load and the ultimate carrying capacity. Using steel links, GFRP and CFRP stirrups of the same area increased the initial cracking load by $29 \%, 35 \%$ and $47 \%$, respectively, and the ultimate capacity by $60 \%, 60 \%$ and $73 \%$, respectively.

3) The CFRP intertwined stirrups was the best strengthening material, which led to highest improvement in the rigidity and ultimate capacity of the tested specimens.

4) The strengthened specimens, either with steel links or FRP stirrups, increased the number of radial cracks.

5) The surface failure of tested specimens forms a nearly square shape with tension slab side.

6) The distance between the column face and the surrounding failure crack was larger in case of strengthened specimens.

7) The equations used to predict the ultimate capacity of the tested specimens gave moderate conservative values, where the experimental values are higher than the calculated ones by $12 \%$ to $29 \%$.

\section{REFERENCES}

[1] F. I. Ehab, "Effect of well-anchored stirrups on punching shear resistance in R.C. slab -column connection," M.Sc. thesis, Cairo university, Faculty of engineering, Department of civil engineering, 1992.

[2] A. M. T. Said, "Strengthening of R.C Slab-Column Connection to Resist Punching Shear," Ph.D. thesis, Faculty of Engineering, Cairo University, 1998.

[3] A. Sherif, "Behavior of Reinforced Concrete Flat Slabs," Ph.D. thesis, University of Calgary, Canada, 1996.

[4] A. Moussa, G. Ghanem, and A. Tarkhan, "Influence of flexural reinforcements on the punching shear capacity of reinforced concrete flat slabs," in Proc. of 5th Alexandria International conference in structural\& Geotechnical Eng., AICSCES, Egypt, Dec.2003.

[5] A. Moussa, "Some additional arrangements to increase the punching shear capacity of reinforced concrete slab-column connections," in Proc. of 2nd Intr. Specialty conference on the conceptual approach to structural design, Milan, Italy, vol. 2, July, 2003.

[6] G. Ismail, A. A. Karem, A. Debeiky, and M. Makhlouf, "Strenghtening and Repair of Reinforcement Concrete Slab-column Connection Subjected to Punching Shear using (CFRP - GFRP - Steel) Stirrups," in Proc. of Fourth International Conference on Structural Stability and Dynamics, India, 2012.

[7] A. M. M. Ramadan, "Repair and Strengthening of Slab-Column Connections with openings," Ph.D. thesis, Faculty of Engineering, Minoufiya University, 2007.
[8] Authorization, "stud rails as shear reinforcement in the support zones of slabs with point supports (zulassungsbescheid Nr. 2-4.6-70, kopfbolzen-dubelleisten als schubbewehrung im stuzenbereich punktforming gestutzter platten)," Institute fur Baulechnik, Berlin, July 1980.

[9] ACI Committee, "Guide for the design and construction of externally bonded FRP systems for strengthening concrete structures," January 2000 .

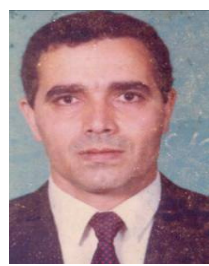

Gamal Ismail Khaleel was born in Damietta on 22 of February of 1958, $\mathrm{PhD}$ in Civil Engineering (effect of axial forces on the shear strength of RC element ) from Department of Civil Engineering, Faculty of Engineering, Cairo University, Egypt, 1992.

$\mathrm{He}$ is Professor of Reinforced Concrete Structures, Faculty of Engineering in Benha and the Vice President, Benha University, Egypt. His publications

and research interests concern with the fields of the strengthening/repair of $\mathrm{RC}$ structures using different techniques.

Dr. Khaleel is a member of Egypt Syndicate of Engineers.

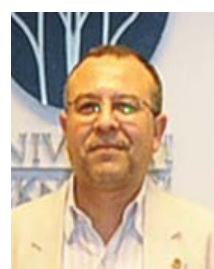

Ibrahim Galal Ibrahim Shaaban was born in Cairo on 1960, $\mathrm{PhD}$ in Civil Engineering from Department of Civil Engineering, Dundee University, Dundee, U.K., 1990.

He is Professor of Reinforced Concrete Structures, Faculty of Engineering at Shoubra, Benha University, Egypt,and the Executive Director of the project Management Unit Development of Higher Education, Ministry of Higher Education.

His publications and research interests concerning with the fields of the strengthening of RC structures using High Strength Concrete.

Dr. Shaabanis a member of Egypt Syndicate of Engineers, Egyptian Society of Engineers and Member of Society for Promoting the use of Bricks and Stones in Buildings.

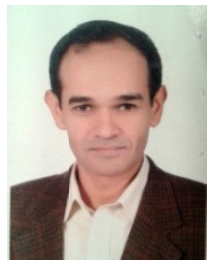

Khaled M. Elsayed was born in Cairo on 15 of December of 1966, PhD in Civil Engineering (structural advanced materials program) from Materials Sciences Department of EscuelaTécnica Superior de Caminos, Canales y Puertos, UniversisdadPolitécnica de Madrid, Spain, 1999.

$\mathrm{He}$ is Associate Professor and the HEAD of Civil Engineering Department, Faculty of Engineering inBenha, Benha University, Egypt. His publications and research interests are concerning with the fields of fracture mechanics of concrete and the strengthening/retrofitting of $\mathrm{RC}$ structures using fiber reinforced polymer materials.

Dr. Elsayed is a member of Egypt Syndicate of Engineers and Egyptian Society of Engineers.

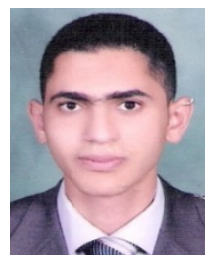

Mohamed Hussein Ali Makhlouf was born in Cairo on 5 of November of 1983, M.SC. in Civil Engineering from Department of Civil Engineering, Faculty of Engineering inBenha, Benha University, Benha, Egypt, 2011.

$\mathrm{He}$ is Assistant Lecturer of Structural Engineering, Faculty of Engineering in Benha, Benha University, Egypt.

His publications and research interests concernwith the field of the strengthening and repair of $\mathrm{RC}$ slab-column connection using different materials and technique.

Eng. Makhlouf is a member of Egypt Syndicate of Engineers. 